\title{
First record of Lingulodinium polyedrum (Dinophyceae) resting cysts in coastal sediments from the Inner Sea of Chiloé, Los Lagos Region, southern Chile $\left(-41^{\circ}-43^{\circ} \mathrm{S}\right)$
}

\author{
Primer registro de quistes de resistencia de Lingulodinium polyedrum (Dinophyceae) \\ en sedimentos costeros del Mar Interior de Chiloé, Región de Los Lagos, sur de Chile \\ $\left(\sim 41^{\circ}-43^{\circ} \mathrm{S}\right)$
}

\author{
Pablo Salgado ${ }^{1}$, Víctor A. Troncoso 2 , Marina Montresor 3 , Marco Salamanca² \& Carina B. Lange 2,4 \\ ${ }^{1}$ Programa de Postgrado en Oceanografía, Departamento de Oceanografía, Universidad de Concepción, Casilla 160-C, \\ Concepción, Chile / Instituto de Fomento Pesquero - IFOP, Enrique Abello 0552, Casilla 101, Punta Arenas, Chile. \\ 2Departamento de Oceanografía, Universidad de Concepción, Casilla 160-C, Concepción, Chile. \\ ${ }^{3}$ Stazione Zoologica Anton Dohrn, Villa Comunale, 80121, Nápoles, Italia. \\ ${ }^{4}$ Centro de Investigación Oceanográfica en el Pacífico Sur-Oriental (FONDAP-COPAS), Programa COPAS Sur-Austral, \\ Universidad de Concepción, Casilla 160-C, Concepción, Chile. \\ pablo.salgado@ifop.cl
}

\section{RESUMEN}

Quistes de resistencia del dinoflagelado potencialmente tóxico Lingulodinium polyedrum (Stein) Dodge son registrados por primera vez en sedimentos costeros del Mar Interior de Chiloé. Se entrega información de abundancia, distribución, descripción y fotomicrografías de la especie. Se confirma la presencia de L. polyedrum en aguas costeras del sur de Chile.

Lingulodinium polyedrum (Syn. Gonyaulax polyedra Stein) is a dinoflagellate that has been associated with the production of yessotoxins (YTXs) (Yasumoto \& Takizawa 1997), red tide and resting cysts during its life cycle (Lewis \& Hallett 1997). Worldwide the YTXs producers have been identified as Protoceratium reticulatum (Claparède et Lachmann) Bütschli, L. polyedrum and Gonyaulax spinifera Dodge (Paz et al. 2004, Rhodes et al. 2006). In southern Chile, Yasumoto \& Takizawa (1997) confirmed the presence of YTXs in shellfish, being the main suspicious species to date, $P$. reticulatum, which has been recorded regularly in vegetative (Guzmán et al. 2010) and cyst (Alves-de-Souza et al. 2009) stages. Unlike L. polyedrum has been cited only in a publication (see Avaria 1992) and G. spinifera seen only sporadically (Guzmán et al. 2010), currently both species are absent in studies of cysts in coastal sediments.

The first record of $L$. polyedrum resting cysts in coastal sediments from the Inner Sea of Chiloé (ISoCh) between $\sim 41^{\circ}$ and $43^{\circ} \mathrm{S}$ (Fig. 1) is presented.

The ISoCh is composed of four micro-basins (Reloncaví Fjord, Reloncaví Sound, and Ancud and Corcovado Gulfs), interconnected by narrow passages between islands giving origin to bathymetric constrictions and sills. Within the ISoCh, the most important constriction is the Desertores
Passage ( $5 \mathrm{~km}$ wide, maximum depth $200 \mathrm{~m}$ ). The water exchange with the adjacent Pacific Ocean occurs through the Chacao Channel, to the north of Chiloé Island $(4 \mathrm{~km}$, maximum depth $50 \mathrm{~m}$ ), and through the Boca del Guafo Passage to the south $(66 \mathrm{~km}, 150 \mathrm{~m}$ depth). In the ISoCh the surface water mass (between 0 and 20-30 m depth; Estuarine Water) moves out from fresh water sources and approaches the ocean, while deep water mass (30-150 m depth; Subantarctic Water) that enter through the Boca del Guafo Passage splits into two branches: one flowing north as far as Seno Reloncaví and the other flowing south. Finally, the most deep water mass (from $150 \mathrm{~m}$ to the bottom; Equatorial Subsurface Water) also come through Boca del Guafo and its displacement to the interior region is limited by the submarine topography, occupies only the deep areas (> 150 m) (e.g. Sievers \& Silva 2008, Silva et al. 2009).

Undisturbed sediment samples were collected using a $\mathrm{KC}$ haps bottom corer in March 2009. The samples were stored in the dark at $4^{\circ} \mathrm{C}$ until further analysis. For cysts identification and enumeration, sample preparation involved sonication, wet sieving $(120 \mu \mathrm{m}$ onto a $20 \mu \mathrm{m})$ following the biological method for cysts cleaning and concentrating (Matsuoka \& Fukuyo 2000). The cysts were counted in a Sedgewick-Rafter chamber using an optical microscope 
(LM) equipped with a digital camera. Further analysis included scanning electron microscopy (SEM), for which the cysts were fixed (2.5\% glutaraldehyde), dehydrated, critical point-dried, sputter-coated with gold and examined with a JEOL JEM 6830 LV scanning electron microscope. Cysts identification was based on its characteristic morphology referring to the specialized publications that describe the species (e.g. Kokinos \& Anderson 1995, Lewis $\&$ Hallett 1997). The results presented here correspond to the integrated analysis of the upper five centimeters of the sedimentary cores collected.

Analysis of sediment samples recorded L. polyedrum resting cysts (Figs. 2-4) from Huenquillahue and Ilque Bays (HIBs), Dalcahue and Hudson Channels (DHCs), and Quellón Bay (QB). Cysts were spherical in shape (32-36 $\mu \mathrm{m}$ in diameter excluding processes), transparent, with a double-layered wall. The cyst wall had a granulose surface ornamented with numerous thick hollow processes variable in length $(6-12 \mu \mathrm{m})$ that tapered distally to a point (Fig. 3). The tips of processes had small granules (Fig. 4). The living cysts had a prominent red accumulation body (Fig. 2).

The horizontal distribution and concentrations of $L$. polyedrum resting cysts in HIBs, DHCs and QB, is shown in Figs 1B, C, D, respectively. Relatively higher densities were observed in QB and lower ones in HIBs. Cysts concentration ranged from not detected (ND) to 7 cysts $\mathrm{ml}^{-1}$ wet sediment in HIBs, ND to 14 in DHCs, and ND to 15 in QB.

Overall, cysts were commonly recorded in 12 out of 24 sampling sites covering the northern, central and southern areas of the ISoCh. The occurrence and densities of cysts decreased from south to north, with the highest densities in the southern area (QB) and minimal densities in the northern bays (HIBs). This S-N pattern may be related to transport by local current and topographic barriers such as the Desertores Passage, which may have acted as a natural barrier restricting the transport of cysts to the north. Thus, according to our results on the distribution of resting cysts, localized areas such as the coastal fringe of QB can be defined as cysts accumulation area.
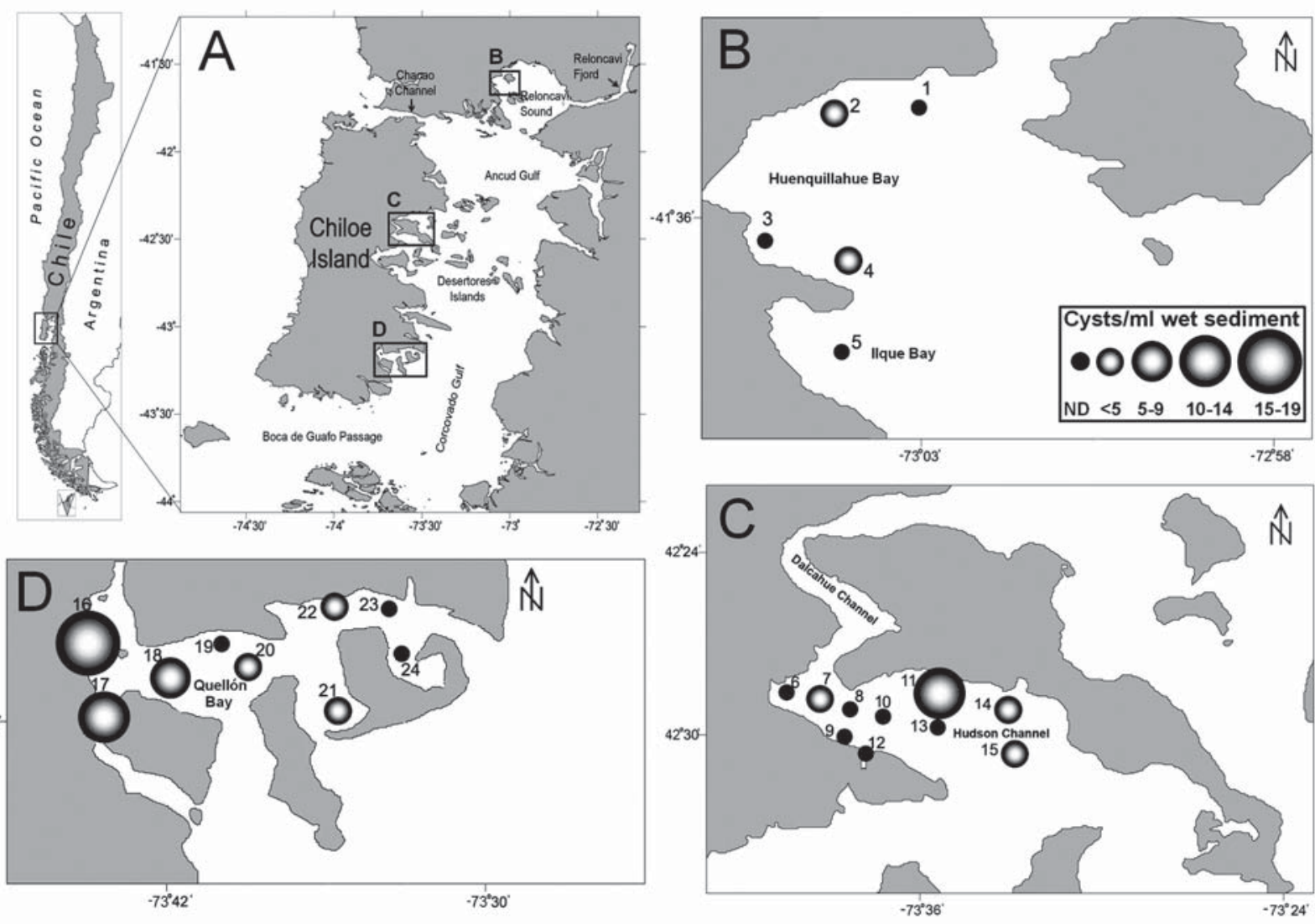

Figure 1. Distribution and abundance of $L$. polyedrum resting cysts in coastal sediments from Los Lagos Region, southern Chile. A: Map of the sampling area. B: Huenquillahue and Ilque Bays (HIBs). C: Dalcahue and Hudson Channels (DHCs). D: Quellón Bay (QB). Numbers on dots refer to coring sites (total of 24).

Figura 1. Distribución y abundancia de quistes de resistencia de L. polyedrum en sedimentos costeros de la Región de Los Lagos, sur de Chile. A: Mapa del área de muestreo. B: Bahías Huenquillahue e Ilque (HIBs), C: Canales Dalcahue and Hudson (DHCs), D: Bahía Quellón (QB). Los números en puntos se refieren a sitios muestreados (un total de 24). 

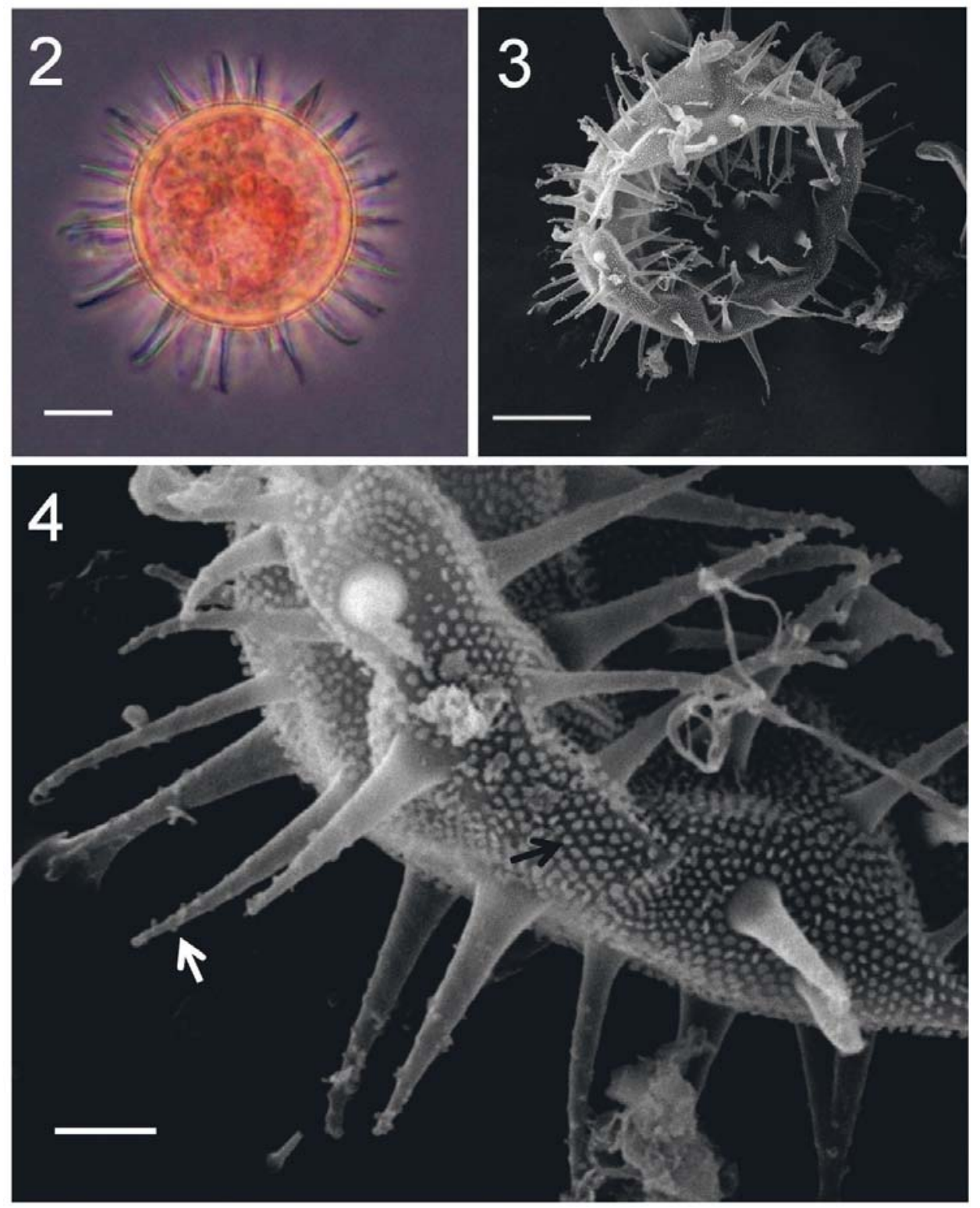

Figures 2-4. Lingulodinium polyedrum resting cysts from Quellón Bay. (2) LM. Living cyst showing a double-layered wall. (3) SEM. Collapsed cyst with numerous processes. (4) SEM. Detailed tips of processes with small granules (white arrow), and granulate surface of cyst body (black arrow). Scale bars: Figures 2 and 3, $10 \mu \mathrm{m}$; Figure 4, $2 \mu \mathrm{m}$.

Figuras 2-4. Quistes de resistencia de L. polyedrum desde Bahía Quellón. (2) ML. Quiste viable mostrando pared de doble capa. (3) MEB. Quiste colapsado con numerosos procesos. (4) MEB. Detalle de puntas de procesos con pequeños gránulos (flecha blanca), y superficie granulada del cuerpo del quiste (flecha negra). Barra de escala: Figuras 2 y $3,10 \mu \mathrm{m}$; Figura 4, $2 \mu \mathrm{m}$.

Since dinoflagellate cysts are formed by plankton stages, the finding of $L$. polyedrum resting cyst in sediments supports the presence of vegetative cells of this potentially YTXs producer species in the water column of the southern Chilean coast. The absence of records of this species in studies and phytoplankton monitoring programs for nearly two decades in Los Lagos Region could be due to several reasons; i.e., it could have been overlooked or incorrectly identified, or seawater samples may have been collected at shallower depths than appropriate, as it is well known that L. polyedrum may migrate deep in the water column (Lewis \& Hallett 1997).

Knowing the abundance and distribution of L. polyedrum resting cysts in sediments of the ISoCh, in addition to its toxin profile, is essential for understanding the ecology and predicting the dynamics of future blooms that could impact human health and economy of the region. 


\section{ACKNOWLEDGMENTS}

This study was funded by project FONDEF MR07I1010 (V.A.T).

\section{REFERENCES}

Alves-De-Souza, C., D. Varela, F. Navarrete, P. Fernández \& P. Leal. 2009. Distribution, abundance and diversity of modern dinoflagellate cyst assemblages from southern Chile (43-54 S). Botanica Marina 51: 399-410.

Avaria, S. 1992. Marea Roja: Perspectiva Científica. Revista de Sanidad de la Defensa Nacional. 9: 92-99

Guzmán, L., G. Vidal, X. Vivanco, V. Arenas, L. Iriarte, S. Mercado, C. Alarcón, H. Pacheco, M. Palma, C. Espinoza, P. Mejías, E. Fernández-Niño, J. Monsalve, V. Hinojosa \& C. Zamora. 2010. Manejo y monitoreo de las mareas rojas en las regiones de Los Lagos, Aysén y Magallanes. Informe Final, III etapa, 238 pp. + Figuras + Tablas + Anexos. Ministerio de Economía. Subsecretaría de Pesca. Instituto de Fomento Pesquero.

Kokinos, J. \& D. Anderson. 1995. Morphological development of resting cysts in cultures of the marine dinoflagellate Lingulodinium polyedrum (=L. machaerophorum). Palynology 19: 143-146.
Lewis, J. \& R. Hallett. 1997.Lingulodiniumpolyedrum(Gonyaulax polyedra) a blooming dinoflagellate. Oceanography and Marine Biology: an Annual Review 35: 97-161.

Matsuoka, K. \& Y. FukuYo. 2000. Technical Guide for Modern Dinoflagellate Cyst Study. HAB/WESTPAC/IOC, Japan. $77 \mathrm{pp}$.

Paz, B., P. Riobó, M. Fernández, S. Fraga \& J. Franco. 2004. Production and release of yessotoxins by the dinoflagellates Protoceratium reticulatum and Lingulodinium polyedrum in culture. Toxicon 44: 251-258.

Rhodes, L., P. McNabb, M. de Salas, L. Briggs, V. Beuzenberg \& M. Gladstone. 2006. Yessotoxin production by Gonyaulax spinifera. Harmful Algae 5:148-155.

Sievers, H. \& N. Silva. 2008. Waters masses and circulation in austral Chilean channels and fjords. In: N. Silva \& S. Palma (eds.), Progress in the Oceanographic Knowledge of Chilean Inner Waters, from Puerto Montt to Cape Horn, pp. 53-58. Comité Oceanográfico Nacional - Pontificia Universidad Católica de Valparaíso, Valparaíso.

Silva, N., J. Haro \& R. Prego. 2009. Metals background and enrichment in the Chiloé Interior Sea sediments there any segregation between fjords, channels and sounds? Estuarine, Coastal and Shelf Science 82: 469-476.

Yasumoto, T. \& A. Takizawa. 1997. Fluorometric measurement of yessotoxins in shellfish by high-pressure liquid chromatography. Bioscience, Biotechnology, Biochemistry 61: $1775-1777$.

Recibido: 27.10 .10

Aceptado: 30.12 .10 